\title{
Enabling Business Model Change: Evidence from High-Technology Firms
}

\author{
Christiana Müller', Stefan Vorbach ${ }^{2}$
}

\begin{abstract}
Companies today face volatile environments, short product life cycles, and changing customer requirements, which is especially the case in high-technology fields. In such environments, concentrating only on technological and product innovations is not sufficient to gain competitive advantages. Instead, companies need innovative business models in order to stand out from their competitors. To successfully change business models, companies require appropriate competencies. Thus, the objective of this research is to identify how companies can prepare their business model(s) to counteract environmental changes flexibly. With the aid of the chosen exploratory, qualitative research design, we investigate companies operating in hightechnology branches. In total, 20 companies participated in our study. The interviews were conducted with CEOs, vice-presidents, product managers or other managers responsible for business model developments. The research revealed that companies can prepare the business model and its elements ex ante through developing capabilities in order to raise the flexibility of the business model. These capabilities have to be developed with regard to several internal and external issues driving these changes.
\end{abstract}

Keywords: business model, business model innovation, capabilities for change, flexibility, high-technology.

\section{INTRODUCTION}

Companies operate in an environment determined by a fast pace, volatility and uncertainty. To survive, they increasingly have to find new ways to gain a competitive advantage. A study by The Economist Intelligence Unit (2005) revealed that $55 \%$ of the CEOs interviewed find new business models to be a greater source of innovation than new products or services. The reason for the rising interest in new business models was explained through increasing choices of products and services on the market and the lack of differentiation between

1 Christiana Müller, Dr., Graz University of Technology, Institute of General Management and Organization, , Kopernikusgasse 24 IV, 8010 Graz, Austria, tel. +43 316873 7502, e-mail: christiana.mueller@tugraz.at.

2 Stefan Vorbach, Prof. Dr., Graz University of Technology, Institute of General Management and Organization, Kopernikusgasse 24 IV, 8010 Graz, Austria, +43 316873 7500, e-mail: stefan.vorbach@tugraz.at. 
them. Moreover, business models change due to commercialization of new technologies (Chesbrough and Rosenbloom, 2002, p. 532), open innovation activities within the company or cooperative partnerships with research institution, suppliers and so on ( Schuh, Friedli and Kurr, 2005, p. 9; Chesbrough, 2006, p. 10). Thus, the development of a new business model is regarded as an essential key to foster firm performance (Zott, Amit and Massa, 2011, p. 1031) and to differentiate from competitors (Styles and Goddard, 2004, p. 65).

High-technology companies operating in sectors like the electronic or pharmaceutical industry do their business in a rapidly changing environment that is shaped by uncertainty in the market and technology, high risks and intensive competition (Evans, 1991, p. 69; Brad, 2007, p. 18). These high-technology companies, characterized for example by a high level of innovativeness, intensive research and development (R\&D) expenditure, highly skilled employees, participation in cooperative networks and a fast pace in terms of obsolescence of products and technologies (ZakrzewskaBielawska, 2010, p. 94), are more often confronted with radical change. Therefore, flexibility is required in order to redefine strategies continuously and find new ways of gaining a competitive advantage (Evans, 1991, p. 69). Flexibility is also required for the business model (BM). It is, hence, not surprising that a study by KPMG International $(2006$, p. 4) postulates the need to develop a flexible and profitable business model by reviewing it on a regular basis, developing a unique value proposition, and working together with partners to pursue new opportunities or strengthen the company's position in the value chain. Moreover, Schuh et al. $(2005$, p. 9) demand an intelligent business model having the capability of being as flexible as needed.

In literature, discussions about the definition of flexibility show a broad variety: Flexibility is described as capacity to adapt (Golden and Powell, 2000, p. 376) and the ability to change oneself in order to remain viable (Krijnen, 1979 , p. 64). From a systems perspective, flexibility can be explained as capability to adaption/change (De Toni and Tonchia, 2005, p. 526) or as the property of a system that can be easily changed (Ferguson, Siddiqi, Lewis and de Weck, 2007, p. 3). Halecker and Hartmann (2013, p. 3) argued that a systemic view is also applicable for business models because they are complex and due to the fact that they are models of a company, they can be seen as open and social systems. Furthermore, a BM can be explained in the form of elements and the relationship between these elements (e.g. Osterwalder and Pigneur, 2010), which is also a characteristic of systems. Thus, the understanding of flexibility from a systems perspective can be transferred in order to explain the flexibility of business models.

Research on BM flexibility is very sparse. Mason and Mouzas (2012, p. 1361) describe the flexibility in business models through adaptability 
in network architecture, market integration, coordination, and business relationships in order to gain better business performance. Taking the airline industry as an example, Nair, Palacios and Tafur $(2011$, p. 3) explain that a flexibility and adaptability layer inherent in the BM can be used for constantly "analyzing, benchmarking, acquiring and strengthening" of necessary competencies for maintaining business performance. These scholars especially highlight the importance of developing and maintaining core competencies (e.g. brand maintenance, product diversification or incremental innovation) to provide flexibility in the BM. Literature on business models (containing several research studies) reflects on capabilities necessary for changing the BM. Factors driving and inhibiting BM changes need specific capabilities in order to enable the change. Driving factors are, for example, rapidly changing customer requirements, the development of customers to co-creators or the deconstruction of the value chain into smaller segments (Schuh et al., 2005, p. 9; Romero and Molina, 2009, p. 403; Capgemini Consulting, 2010, p. 12). In contrast, inhibiting factors are inertia regarding existing competencies or technologies, just to name a few (Chesbrough, 2010, p. 358). As descriptions on capabilities are quite general, Schneider and Spieth (2013, p. 21) emphasized that more in-depth research is required in defining capabilities to innovate the BM, depending on the particular element and type of business model innovation, and the need to develop these capabilities ex ante. Due to the existence of solely general descriptions of capabilities, such a holistic description is still missing. Referring to Schneider and Spieth (2013, p. 21), they further explain the need for an ex ante development of capabilities for single elements, as well as for the overall BM. Using this approach, we see flexibility as the ability of the BM and its single elements to adapt to changes and exploit opportunities in the future. This postulates the need to develop capabilities and properties enabling flexibility in the BM and its single elements, as also explained in the literature on flexibility in systems (e.g. Brehm, 2003, p. 45). Consequently, the focus and goal of our paper is to provide an integrated view about properties and capabilities necessary, in single $\mathrm{BM}$ elements and the overall $\mathrm{BM}$, to provide the flexibility required to adapt to changing needs.

The remainder of this paper is organized as follows: The next section provides the related theoretical background on business models, BM change and capabilities necessary to change the BM. After the description of the research design, the empirical findings on identified capabilities and properties enabling BM change are explained. Next, the empirical findings are discussed and implications are given for practitioners and research. The paper ends with a summary of the findings and limitations. 


\section{Business model and necessary capabilities to change the BM}

In general, "a business model describes the rationale of how an organization creates, delivers, and captures value" (Osterwalder and Pigneur, 2010, p. 14). The emergence of the BM concept is mainly perceived with the appearance of the new economy and e-commerce between 1998 and 2002. Afterwards, the concept was also increasingly adopted in the "old economy" and evolved to become a strategic component. (Wirtz, 2011, p. 14) The development of the BM concept in different scientific disciplines led to various definitions, but a general understanding does not exist so far. This is also true for concepts describing business model innovation.

Business model definitions appear in different forms and degrees of abstraction, like in a narrative description (e.g. Magretta, 2002, p. 87), in form of graphical frameworks (e.g. Osterwalder and Pigneur, 2010, p. 18 ) or described as activity system (e.g. Zott and Amit, 2010, p. 217). The majority of definitions consider the BM as an abstract view on the company, with the focus on describing different dimensions or elements that fit together and shape the BM. These descriptions correspond with specified graphical frameworks, but also differ in the number of elements defined and their detailed description and complexity. Also our interview partners had differing granularity when describing their BM. A broad and common understanding existed about the necessity to know who the customers are and what value in terms of products and services are delivered to them. In turn, other practitioners explained the value creation and value capture as elementary elements. Summing up, we experienced in our interviews that companies deem four elements relevant (see figure 1): The customer element representing the target group of the company's offerings and channels to reach them; the value proposition explaining what is delivered to the customer in order to fulfill the needs of the target group; the value creation describing how the value is generated; and the value capture determining the added value in form of revenues generated from the value proposition as well as the costs incurred as a result of value creation. This explanation of a BM is not completely new, but represents the perception of a BM from the perspective of our interviewed practitioners.

Besides the definition of specific BM elements, their interrelation and alignment is also important. This becomes more transparent through cause and effect relationships (Hedman and Kalling, 2003, p. 53). Thus, the BM elements identified should not be treated as stand-alone elements; rather they are connected and influence each other. For example, when our interview partners reported about the customer focus, the alignment of the entire $\mathrm{BM}$ according to this focus is emphasized, describing implicitly the alignment of all BM elements towards customer needs and, therefore, the 
customer element. Hence, the BM in figure 1 represents the interrelationship between the BM elements as well.

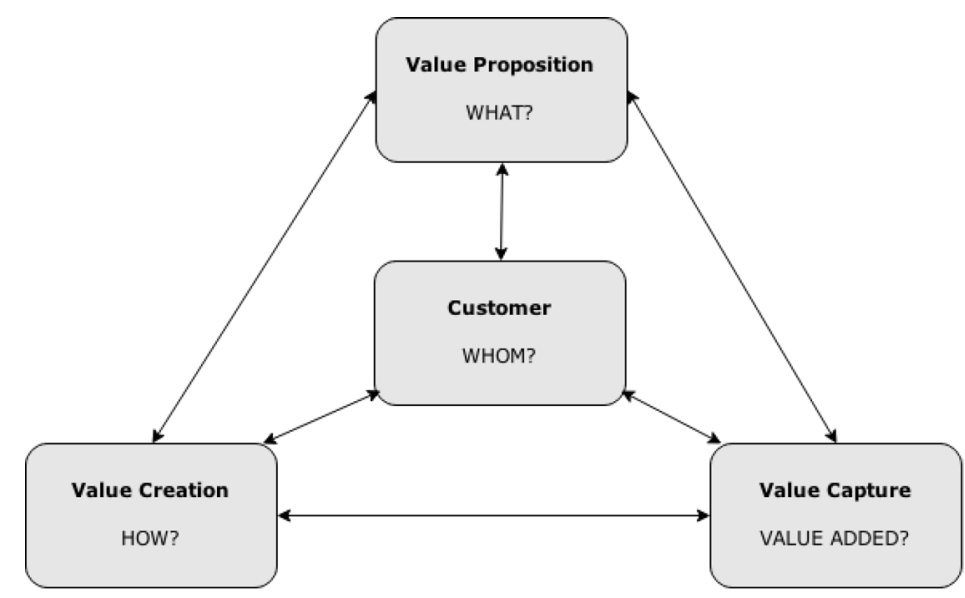

Figure 1. Business model elements

Source: Müller (2014).

Once the BM concept established in the new economy, companies in the "old economy" started to rethink their existing BM. With these changes in established business models, terms like business model change or business model innovation emerged. This new scientific discussion has become increasingly important in the past few years. (Zollenkop, 2006, p.31)

In order to recognize the need for BM changes and turn the BM change into success, companies need to develop specific capabilities. Within BM innovation literature the identification of capabilities and basic conditions (e.g. organizational culture) gained more importance in recent years. One particular concept discussed in that context is the dynamic capabilities concept. Dynamic capabilities are a prerequisite for changing a company's way of doing business in order to survive and prosper under constantly changing conditions (Helfat et al., 2007, p. 1). These are an advancement of the resource-based view because this theoretical explanation is criticized as being too static. Teece, Pisano and Shuen (1997, p. 516) mainly contributed to this concept's development by providing one of the first definitions: Dynamic capabilities are "the firm's ability to integrate, build and reconfigure internal and external competences to address rapidly changing environments". In their view, the dynamism is determined by the capacity of the organization to renew its competencies according to the changing business environment. In 
a BM, resources and competencies are an integral part of the value creation element. Thus, dynamic capabilities are seen as relevant for the BM change. Several scholars built on the research stream originated by Teece et al. (1997) and mentioned sensing, seizing and reconfiguration as important capabilities when it comes to changes in the BM. In concrete, these dynamic capabilities are manifested in sensing market or technological opportunities, exploiting these opportunities by changing the $\mathrm{BM}$ and preparing the organization according to the new direction. (Dottore, 2009, p. 491; Mezger, 2013, p. 6) Further, the establishment of learning processes plays an important role. Learning processes should support companies to handle problems and challenges in the industry and to re-combine existing knowledge (Najmaei, 2011, p. 167).

Changing the BM is a managerial task. Mitchell and Coles (2003, p. 20) brought into discussion that the CEO has to be aware of the importance of changing the BM in order to better serve customers and other stakeholders. Management tasks span the sensing and seizing of both opportunities and threats and preparing the organization for that. The development of dynamic capabilities for changing the BM, as previously explained, is thus helpful. Furthermore, managers are also essential for eliminating barriers to change and enhancing the opportunity to implement the new BM successfully. However, managers themselves can be a barrier to change if they are not skilled and willing to change the existing BM (Massa and Tucci, 2013, p. 13; Gassmann, Frankenberger and Csik, 2014, p. 341). The significance of a strong leadership when changing the BM was also revealed in the study by KPMG International (2006, p. 59). Deschamps $(2005$, p. 35) explained that the implementation of a new BM requires a "pragmatic architect" who is able to define the operating system in detail and possesses project management skills. At the same time, the importance of establishing a culture that appreciates change is highlighted by several scholars. According to Gassmann et al. (2014, p. 342), corporate culture is an important success factor in change activities.

As shown in this section, dynamic capabilities, management and leadership, as well as a corporate culture appreciating change are important factors when shifting the BM. Our study takes these findings into consideration.

\section{RESEARCH METHODS}

For this research, an exploratory, qualitative research design in the field of high-technology industries was chosen. The qualitative research design is appropriate when questions are formulated as explorative what-questions (Yin, 2009, p. 28) but also when the goal is to understand meanings or events and actions in a specific context (Maxwell, 2005, p. 22). The high-technology 
industry seems to be an appropriate context for this research because high-technology companies face a high speed of change and volatility and technological changes are very often accompanied by BM changes (Chesbrough and Rosenbloom, 2002, p. 532).

As a basis for our research process, the approaches proposed by Eisenhardt (1989) and Gioia, Corley and Hamilton (2012) were used. The procedure described by Eisenhardt $(1989$, p. 532$)$ is a combination of the case study method and the grounded theory approach. The method explained by Gioia et al. (2012, p. 1) relies entirely on grounded theory, but aims to apply more rigor in this inductive approach. Additional reasons for choosing a combination of these two processes are that both research procedures are especially advantageous in new research topics. Both consider the existing literature prior to the study and both are established research procedures in their fields.

\section{Case selection and data gathering}

In our study, the procedures of theoretical and purposive sampling were used to choose the company cases. Theoretical sampling is an iterative process in which data gathering and data analysis alternate (Birks and Mills, 2010, p. 69) and the sample is not determined in advance. Alternate data gathering and analysis continues until theoretical saturation is reached and adding more material does not result in additional insights. With purposive sampling, the cases are chosen purposefully for the study (e.g. only extreme cases, typical cases, access to interview partners) (Flick, 2014, p. 109). For our research, a mixture of theoretical and purposive sampling was chosen because some criteria for selecting the cases were determined in advance. This complies with purposive sampling as these criteria help to identify cases that are best suited to examine the phenomenon. Pragmatic reasons like the accessibility of interview partners were also taken into consideration. In line with theoretical sampling, the cases actually investigated were chosen in an iterative process of data gathering and analysis. The following criteria were defined for this purpose:

- Companies are classified as high-technology and medium-high technology according to NACE Rev2. According to this classification, companies established in group 21 - manufacturing of basic pharmaceutical products and pharmaceutical preparations, group 26 - manufacturing of computer, electronic and optical products, as well as group 30.3 - manufacturing of aircraft, spacecraft and related machinery are designated as high-technology. (EUROSTAT, 2014) In addition to companies which are defined by NACE Rev. 2 as purely high-technology, companies in the medium-high technology 
classification were also included in the sample. We did so because the boundaries between the classification of medium-high and high-technology are sometimes blurring and we assumed that these companies face the same challenges as purely high-technology companies. Thus, medium-high technology companies are considered if innovation is seen as an important issue in their business (e.g. obtained innovation award).

- Companies are independently managed (e.g. single organizations, independent divisions or business units).

- Companies are established and of medium or large size.

- Headquarters and/or single divisions or business units are located in Austria. This restriction has pragmatic reasons, such as access to interview partners and additional materials (e.g. annual reports).

Table 1 contains the list of companies in the sample. To guarantee anonymity, we labeled the companies alphabetically starting with A, like Company A. The table further presents the company's NACE classification as well as information about the number of employees in the corporate group and the business unit/subsidiary considered, the location of the headquarters (HQ) and the position of the interview partner in the company.

Table 1. List of high-technology companies included in the research

\begin{tabular}{|c|c|c|c|c|c|}
\hline Company & $\begin{array}{l}\text { Number } \\
\text { of em- } \\
\text { ployees }\end{array}$ & $\begin{array}{l}\text { NACE } \\
\text { classify- } \\
\text { cation }\end{array}$ & Detailed description & HQ & $\begin{array}{l}\text { Position interview } \\
\text { partner }\end{array}$ \\
\hline Company A & 1,394 & 26.110 & $\begin{array}{l}\text { Development and factory-made } \\
\text { micro-electronic components, } \\
\text { so called "Micro-Chips". }\end{array}$ & AUT & $\begin{array}{l}\text { Senior Vice } \\
\text { President \& } \\
\text { General Manager }\end{array}$ \\
\hline Company B & $\begin{array}{l}2,860 / \\
150\end{array}$ & 29.310 & $\begin{array}{l}\text { Development of electromagnets } \\
\text { as well as electromagnetic } \\
\text { brakes. }\end{array}$ & NE & $\begin{array}{l}\text { CEO of one } \\
\text { Business Unit }\end{array}$ \\
\hline Company C & 100 & 26.110 & $\begin{array}{l}\text { Microcontroller-based motor } \\
\text { controls and controls for } \\
\text { ergonomic solutions in the } \\
\text { furniture industry. }\end{array}$ & AUT & $\begin{array}{l}\text { Business Unit } \\
\text { Manager \& } \\
\text { Director Sales }\end{array}$ \\
\hline Company D & $\begin{array}{l}5,266 / \\
3,013\end{array}$ & 28.290 & $\begin{array}{l}\text { Production and sales of } \\
\text { public communication } \\
\text { systems for switching and } \\
\text { transition technology, private } \\
\text { communication systems and } \\
\text { traffic control technology. }\end{array}$ & AUT & $\begin{array}{l}\text { Chief Marketing } \\
\text { Officers for the } \\
\text { Corporate Group } \\
\text { \& Vice President } \\
\text { for Marketing \& } \\
\text { Communications } \\
\text { for a Business Unit }\end{array}$ \\
\hline Company E & $\begin{array}{l}8,284 / \\
1,787\end{array}$ & $\begin{array}{l}26.300 / \\
26.541\end{array}$ & $\begin{array}{l}\text { Research, development, } \\
\text { production and sales of } \\
\text { electronic and electronic } \\
\text { components of all kinds. }\end{array}$ & AUT & $\begin{array}{l}\text { Head of Business } \\
\text { Development }\end{array}$ \\
\hline Company F & $\begin{array}{l}>6,500 / \\
540\end{array}$ & 26.110 & $\begin{array}{l}\text { Development of equipment, } \\
\text { specific machines and } \\
\text { accessories for the } \\
\text { semiconductor industry. }\end{array}$ & USA & $\begin{array}{l}\text { COO \& Managing } \\
\text { Director } \\
\text { Operations Head }\end{array}$ \\
\hline
\end{tabular}




\begin{tabular}{|c|c|c|c|c|c|}
\hline Company G & $\begin{array}{l}1,500 / \\
390\end{array}$ & $\begin{array}{l}23.430 / \\
23.990\end{array}$ & $\begin{array}{l}\text { Manufacturing of electrical } \\
\text { insulating materials, technical } \\
\text { laminates and composites. }\end{array}$ & AUT & $\begin{array}{l}\text { Manager Business } \\
\text { Development }\end{array}$ \\
\hline Company H & $\begin{array}{l}38,000 / \\
320\end{array}$ & 21.200 & $\begin{array}{l}\text { Manufacturing of } \\
\text { pharmaceutical specialties } \\
\text { and additional pharmaceutical } \\
\text { products. }\end{array}$ & $\mathrm{DE}$ & $\begin{array}{l}\text { Head of Change \& } \\
\text { Innovation }\end{array}$ \\
\hline Company I & 297 & 26.700 & $\begin{array}{l}\text { Manufacturing of fine- } \\
\text { mechanical and optical } \\
\text { instruments and machines. }\end{array}$ & AUT & $\begin{array}{l}\text { Marketing \& } \\
\text { Global Product } \\
\text { Manager }\end{array}$ \\
\hline Company J & $\begin{array}{l}>1,600 / \\
>920\end{array}$ & 26.510 & $\begin{array}{l}\text { Development, manufacturing } \\
\text { and distribution of high- } \\
\text { precision } \\
\text { PC-based measurement } \\
\text { systems. }\end{array}$ & AUT & $\begin{array}{l}\text { Development } \\
\text { Corporate Plant }\end{array}$ \\
\hline Company K & 300 & 28.290 & $\begin{array}{l}\text { Manufacturing of individual } \\
\text { production systems and } \\
\text { automation-solutions. }\end{array}$ & AUT & $\begin{array}{l}\text { Head of Business } \\
\text { Development }\end{array}$ \\
\hline Company L & $640 / 71$ & 26.510 & $\begin{array}{l}\text { Development, manufacturing } \\
\text { and distribution of high- } \\
\text { precision PC based } \\
\text { measurement systems. }\end{array}$ & $\mathrm{DE}$ & CEO \\
\hline Company M & 980 & $\begin{array}{l}26.300 / \\
26.510\end{array}$ & $\begin{array}{l}\text { International provider of } \\
\text { communication and information } \\
\text { solutions for safety-critical } \\
\text { fields. }\end{array}$ & AUT & $\begin{array}{l}\text { Product Manager } \\
\text { \& Business } \\
\text { Development }\end{array}$ \\
\hline Company N & n.a./90 & 20.140 & $\begin{array}{l}\text { Manufacturing of silage } \\
\text { additives and probiotics. }\end{array}$ & AUT & CEO \\
\hline Company $\mathrm{O}$ & $\begin{array}{l}31,961 / \\
1,000\end{array}$ & $\begin{array}{l}21.200 / \\
20.200\end{array}$ & $\begin{array}{l}\text { Development, production and } \\
\text { sales of special pharmaceutical } \\
\text { products and active agents. }\end{array}$ & $\mathrm{DE}$ & $\begin{array}{l}\text { Executive Vice } \\
\text { President \& } \\
\text { General Manager }\end{array}$ \\
\hline Company $\mathrm{P}$ & 2,450 & 26.510 & $\begin{array}{l}\text { All-in-one solution provider of } \\
\text { intra-logistic complete solutions } \\
\text { and automated warehouse } \\
\text { systems. }\end{array}$ & AUT & CEO \\
\hline Company Q & 7,321 & 26.110 & $\begin{array}{l}\text { Manufacturer of high-end } \\
\text { printed circuit boards. }\end{array}$ & AUT & $\begin{array}{l}\text { Business } \\
\text { Development } \\
\text { Corporate Group } \\
\text { \& CFO Business } \\
\text { Unit }\end{array}$ \\
\hline Company $\mathbf{R}$ & 730 & $\begin{array}{l}28.120 / \\
26.110\end{array}$ & $\begin{array}{l}\text { Planning, manufacturing and } \\
\text { distribution of hydraulics, } \\
\text { electronics, sensoric, electrical } \\
\text { engineering and electrical } \\
\text { installations. }\end{array}$ & AUT & $\begin{array}{l}\text { Head Business } \\
\text { Development }\end{array}$ \\
\hline Company S & $\begin{array}{l}>450 / \\
57\end{array}$ & 28.290 & $\begin{array}{l}\text { Planning and developing of } \\
\text { special machine projects. }\end{array}$ & $\mathrm{DE}$ & CEO \\
\hline Company $\mathrm{T}$ & 113 & 28.999 & $\begin{array}{l}\text { Development of technologies } \\
\text { for energy generation; } \\
\text { leading specialist in plant } \\
\text { manufacturing, providing of } \\
\text { customized turnkey solutions. }\end{array}$ & AUT & $\begin{array}{l}\text { Member Executive } \\
\text { Board \& CSO }\end{array}$ \\
\hline
\end{tabular}

Source: Müller (2014). 
Data was gathered by means of semi-structured expert interviews with representatives from the top management team (e.g. CEO, executive vice president). Semi-structured interviews are a common method of data gathering in qualitative research and are used when the interview partner occupies complex knowledge on a specific topic (Gioia et al., 2012, p. 5). Expert interviews are a special form of semi-structured interviews, where the interview is conducted with experts (Flick, 2014, p. 227). Experts are people who command specific knowledge, information and competencies in their field, are responsible for the design, implementation and controlling of a solution or have privileged access to information (e.g. decision processes) (Bogner, Littig and Menz, 2009, p. 7). We decided to interview one person at each company due to the difficulty of obtaining an appointment with appropriate interview partners. The interviews were conducted face-to-face at the company site between July 2013 and May 2014. The length of the interviews ranged from 0.5 hour up to 1.5 hours.

In qualitative studies, especially the grounded theory, researchers are skeptical towards considering theoretical knowledge prior conducting the study. However, both Eisenhardt (1989, p. 536) and Gioia et al. (2012, p. 12) recommend to consider the existing literature and develop theoretical constructs at the beginning. Nevertheless, they advise to treat these theoretical constructs as temporary available that can be rejected or changed during the process. We structured our interview guideline to start with discussions about the existing BM of the company, threats and opportunities that might lead to BM changes, capabilities necessary to change the BM and how companies prepare their BM in order to change it according to emerging opportunities and threats. To provide the basis for an open dialogue, our questions were worded in a very open manner and we had the opportunity to probe and discuss certain aspects in detail. Prior to the interview, the interviewees received only the rough topics of the interview. This should prevent from preparing the exact answers to all questions in advance. Besides the primary data gathered in the interviews, secondary data in the form of information on web sites, press releases or documents and reports available from the company were considered. These secondary data were used to gain additional insights into the companies.

\section{DATA ANALYSIS}

All 20 interviews were analyzed by using the MAXQDA 11 software tool. For the data analysis procedure, we chose a combination of the structuring qualitative content analysis described by Mayring (2010, p. 67) as well as the analysis explained by Gioia et al. (2012, p. 6) which is based on grounded 
theory. We developed a provisional coding scheme that was used for structuring the data gathered. This coding scheme was grounded on the topics of our semi-structured interview guideline. Afterwards, the structured text was coded in order to develop 2nd order themes as described by Gioia et al. $(2012$, p. 6). A system of categories was established by aggregating these 2nd order themes. The analysis was conducted first of all for each individual company, followed by a cross-case analysis where the results of individual cases were compared and critical categories generated. Table 2 provides a snapshot of the coding scheme and category development. The previously considered theory increased theoretical sensitivity and was supportive in category generation. These steps were conducted in an iterative process until theoretical saturation was reached. In our research, theoretical saturation was achieved when no new categories emerged even if adding new empirical material. To refine categories and develop causal relationships between them, the original data were screened again with the system of categories emerging. This follows the idea of deductive and more confirmatory content analysis, as explained in the structuring content analysis by Mayring (2010, p. 67).

Table 2. Snapshot of coding scheme

\begin{tabular}{|c|c|c|}
\hline Paraphrase & $2^{\text {nd }}$ order theme & Category \\
\hline $\begin{array}{l}\text { Accepting change as something normal and understanding why } \\
\text { the change has happened. There must be a strong appreciation } \\
\text { of dealing with something new and a basic readiness to make } \\
\text { changes. }\end{array}$ & \multirow[t]{2}{*}{$\begin{array}{l}\text { Willingness to } \\
\text { change }\end{array}$} & \multirow[t]{4}{*}{$\begin{array}{l}\text { Change } \\
\text { readiness }\end{array}$} \\
\hline $\begin{array}{l}\text { Have no taboos and be open for every topic. It is important } \\
\text { to realize that every business model has an expiry date; the } \\
\text { openness to say that the company or the business model is } \\
\text { replaceable must be realized. }\end{array}$ & & \\
\hline $\begin{array}{l}\text { Flexible communication is important to mediate between } \\
\text { customer needs and requirements and what the company is } \\
\text { able to provide. }\end{array}$ & \multirow[t]{2}{*}{ Communication } & \\
\hline $\begin{array}{l}\text { The person responsible for the change needs to communicate } \\
\text { it. Commitment can only be generated through communication. }\end{array}$ & & \\
\hline
\end{tabular}

\section{FINDINGS}

As basis for identifying enablers in terms of properties and capabilities providing flexibility, our BM consisting of four elements - value proposition, value creation, value capture and the customer element (Müller, 2014, p. 156) - was used. These properties and capabilities were identified with respect to internal and external factors driving changes in the BM, and are necessary for covering these driving factors. More precisely, properties and capabilities 
were identified in three BM elements: Value proposition, value creation and the customer element. In addition, companies reported about capabilities necessary to prepare the overall BM for a change. Table 2 summarizes the properties and capabilities identified.

Table 3. Empirical findings on capabilities and properties enabling BM change

\begin{tabular}{ll}
\hline & Capabilities/Properties for BM change \\
\hline Value Proposition & Product modularity \\
Value Creation & Establishment of external partnerships \\
& Competence robustness \\
Customer & Task and process versatility \\
& Sense and accumulate information on customer needs \\
& Market sensitivity \\
Entire Business Model & Change readiness - openness and willingness to change, open \\
& communication, having the right people \\
& Management of risks and learning \\
& Leadership and commitment \\
& Organizational preparation \\
\hline
\end{tabular}

Source: Müller (2014, p. 182).

The following detailed descriptions are reinforced by providing one to two explanatory examples from the empirical data gathered.

\section{Capabilities and properties identified in specific BM elements}

Product modularity was identified as driving the flexibility potential at the value proposition. Customers require tailor-made solutions that suit to their needs perfectly. Thus, companies need to find a way to develop and provide products and services according to these needs and have to develop the value proposition accordingly. Company $\mathrm{M}$ explains the requirements for modular products as follows (oral information, 21 April 2014):

"[...] our customers require tailor-made solutions. It is extremely costly to provide customized solutions every time. Thus, 10 years ago we started to manufacture products providing flexible, tailor-made solutions. [...]"

Thus, the companies interviewed highlighted the importance of modular product architecture in order to reduce the product's complexity and adapt to market trends and customer requirements or pursue growth activities within the company.

In the value creation, three flexibility potentials were identified: Establishing external partnerships, competence robustness as well as task and process versatility. The establishment of external partnerships is helpful 
because network partners provide flexibility in many ways. Partners can be seen as a resource possibly offering external competencies; or they provide capacities (e.g. in manufacturing) if internal capacities are fully utilized. For example, company $\mathrm{P}$ uses network partners to source capacities in terms of manufacturing or development. They treat the external environment as a slack resource that provides flexibility. Moreover, partners provide new and interesting topics (e.g. market trends, technological developments) that are important to seize future BM opportunities or prepare for future restrictions and regulations, which is especially important in the pharmaceutical industry.

Competence robustness was also emphasized by the companies interviewed. They describe competence robustness by aligning the BM on core competencies that can be extended through innovation if opportunities for new ventures emerge. This goes along with the establishment of external partnerships because non-core competencies and resources are sourced externally. These robust core competencies act as a "tower of strength" in an area of uncertain and unforeseeable developments. Moreover, they provide the basis for the development of a company's value proposition and also stability in uncertain and volatile environments. Enhancing these core competencies can create additional opportunities (e.g. new value proposition) to perceive further growth potentials and outstanding results. Company A possesses the core competency of developing microchips on which the BM is based on. In order to serve customers in a better way, their core was extended by adding additional distribution channels.

Companies further reported on the importance of task and process versatility for handling change requirements. A certain degree of versatility is needed, mainly in perception of specific customer or reorganization requirements due to growth activities or cost pressure. In the BM of company $\mathrm{C}$, processes are clearly defined to ensure the quality of products. Nevertheless, the company attempts to adjust fitting to customer needs (e.g. receive value proposition faster).

In the customer element, the capability to sense and accumulate information on customer needs was reported to be important. The interviewed companies consider the customer as the core of their BM. Growth activities pursued by the company and the demand to fulfill customer needs require proximity to the customer in order to anticipate and integrate needs into the $\mathrm{BM}$ at an early stage. This requires sensing of customer requirements, but also accumulating and processing them throughout the company. Company $G$ reported that information about customer needs has to be available for everyone in the company. For this purpose, they implemented a CRM tool that supports them in providing the customer information. 


\section{Capabilities and properties identified in the overall BM}

Several capabilities were reported that ensure the changeability of the overall BM. Thus, they are not assigned to a specific BM element. These capabilities are seen as meta-capabilities because they are considered as a general precondition enabling change.

Sensitivity towards changes and developments in the market is imperative for sensing and seizing market trends. It helps to identify and fulfill customer requirements and to prepare in advance for handling legal restrictions and regulations as well as situations of crisis. Companies take several actions in this respect, such as constant market research and analysis, discussions with branch experts or simulation of developments in the market. To increase sensitivity towards market developments in the pharmaceutical industry, company $\mathrm{O}$ works closely together with public authorities and customers. In doing so, company $\mathrm{O}$ participates in committees to obtain information and discuss about future reforms and regulations early on. Furthermore, company $\mathrm{O}$ organizes special events with customers to debate on current and future issues in pain therapy in order to develop corresponding solutions.

Change readiness expresses the general ability of a company to handle situations of change. It is mainly shaped by the corporate culture, describing conventions on how to handle activities of change within the organization. Thus, it is defined as how changes are communicated within the organization as well as how employees experience and deal with unfamiliar situations. Factors such as openness towards and willingness to change, open communication and appropriate people to make the new direction possible are required. Especially changes in the BM very often lead to changes in the way how the company operates. This often goes in line with skepticism and fears of employees. Company R, therefore, emphasizes to have no taboos and be open for every topic. They draw the attention to the fact that every BM has an expiry date and business models are replaceable.

Both, risks and learning need specific management processes, institutionalized within the company. Companies need to be aware in advance of the risks involved in the actions taken, but they also need to take appropriate risks in order to learn and improve. Therefore, an active management of risks and learning is advisable. Risks taken in new opportunities may provide additional revenues, but also help to learn from mistakes. Activities for managing possible risks in the ecosystem of the company should help to prepare countermeasures in advance. Company A implemented a plan-docheck-act cycle to show variances and develop countermeasures if needed. In comparison, company $\mathrm{C}$ conducts risk assessments and develops different scenarios of possible market evolutions. 
Leadership and commitment of the management team is necessary on the one hand to enhance the willingness to change within the organization, and on the other hand to support the implementation of change initiatives. Managers occupy an important position when it comes to BM changes. First, they need the experience and skills to identify changes but also have to be empowered to realize them within the organization. Second, when it comes to implementation, the commitment of the management team is essential as it is an important precondition for implementing directional shifts of the BM successfully. Company $\mathrm{F}$ highlighted that the most important capability in driving a BM change is the managers' gut feeling, which they see as an important part of leadership. Besides that, company L emphasized, that managers need the authorization and experience to develop further or change the BM.

Preparing the organizational structure allows companies to grow further as well as to recognize and pursue business opportunities much faster. Several examples were reported during the interviews. Company P referred about the change from a centralized to decentralized decision making. The establishment of groups responsible for the processes and tasks in their task pane and, therefore, also for possible changes, was reported by company $\mathrm{H}$. For the companies, these reorganizations support to increase the speed of actions because decisions are decentralized to where the information and competencies are available. Thus, established structures, processes and responsibilities need to be shifted.

\section{Discussion}

In our empirical study we investigated in several capabilities and properties in BM elements and in the entire BM to enable a flexible action and reaction, respectively. Some of our findings are already discussed in the literature on flexibility, changing the company but also in relation to BM changes, with the focus on predominantly highlighting single capabilities providing flexibility and enabling change. The purpose of our study was to empirically research on capabilities and properties in the context of BM changes. We especially shed light on an integrated view, where we do not point out single capabilities or properties enabling flexibility in the BM. Instead, we provide a picture of how a conscious preparation of the BM can be achieved. Furthermore, our goal was to empirically explain how single elements and the overall BM can be configured more flexible in order to deal with and change according to different internal and external needs. Capabilities and properties emerged in three out of four BM elements: 
- To enable flexibility in the value proposition, product modularity emerged as important. Existing literature discusses modularity as important precondition for adding or removing product lines (Almeida, Oliveira and Cruz, 2009, p. 31) or "facilitate flexible business models" in the development of a networked BM (Palo and Tähtinen, 2011, p. 377).

- In the value creation, the two factors establishing external partnerships and competence robustness are recently discussed in the BM literature: Cooperation is seen as a good way to enhance flexibility in the $\mathrm{BM}$ and reduces risks by sharing capacities (Mason and Mouzas, 2012, p. 1362). KPMG International (2006, p. 6) highlighted the importance of establishing " $a$ defendable position in the value chain" by concentrating on those activities where they are strongest. Versatility is defined as being "capable of dealing with many subjects" (Bahrami and Evans, 2005, p. 16p) that is also the sense of task and process versatility, the third factor in value creation.

- For the customer element, the necessity to sense and accumulate information on customer needs was identified as important to facilitate change. This can be attributed to the strong customer focus of the companies interviewed, experiencing the customer as a powerful driver of BM changes. This is discussed as important dynamic capability (Teece, 2007, p. 1322) and also as important capability in the BM literature (Dottore, 2009, p. 491; Mezger, 2013, p. 6).

- In the value capture, no capabilities and properties enabling BM flexibility were identified. We observed that costs, as the consequence of value creation, are often drivers of BM changes. Furthermore, the value capture needs to adapt as a result of changes in other BM elements.

Most of our capabilities identified enable flexibility of the overall BM. In our research, especially the factors determining the readiness for change were stressed by the companies interviewed. Change readiness includes the willingness to change, open communication and skilled people who are willing to recognize improvements, make changes and think out of the box. A particular significance is also attributed to the corporate culture that emerged as an important precondition to enable changes in the BM. In conjunction with BM changes, this was already discussed by Gassmann et al. (2014, p. 341) and described by Achtenhagen, Melin and Naldi (2013, p. 431) as a critical capability to exploit business opportunities. Companies also pointed out the importance of managing risks and learning as well as to prepare accordingly. Countermeasures taken by the companies interviewed include the monitoring and active planning of risks that may harm the business success. We also revealed the significance of leadership and the management commitment to changes or the preparation of the organization for fast 
decision-making, growth and implementation of changes. Managers play an important role because they need to recognize the necessity for change, drive this necessity and deal with associated risks (Charitou and Markides, 2003, p. 60; Demil and Lecocq, 2010, p. 241). Gassmann et al. (2014, p. 342) explained the importance of the management's commitment to change activities in the BM and to involve all employees in order to raise motivation and overcome barriers to change. The enhancement of flexibility due to a reduced complexity in organizational design was already argued by Bock, Opsahl, George and Gann (2012, p. 299). Furthermore, a study by Capgemini Consulting (2010, p. 12) revealed the significance of decentralization to align the focus of the BM on the customer. Based on these findings, the following implications for practitioners and research exist.

\section{Implications for practitioners}

For industry, the results postulate the necessity to understand one's BM conscientiously. This is helpful for preparing the BM accordingly to enable flexible action and reaction to changing needs. During the interviews we noticed that companies know their business models often quite well but have different understandings in terms of details and BM focus. However, most of them are not familiar with a system-oriented thinking of BM elements like the BM we proposed in this paper (see figure 1). The vast majority of participating companies changed and improved their BM in the course of strategic meetings and not by using any specific BM concept or tool. Moreover, we also observed that companies are very keen on understanding how to use $\mathrm{BM}$ concepts and tools to improve their BM so as to distinguish themselves from competitors, identify potential business opportunities and think out of the box. This requires the usage of the BM as strategic tool, where companies give their attention to single elements as well as their interrelationship and the alignment of the overall BM.

Our findings revealed that companies can enable and enhance BM flexibility by a conscious preparation of single BM elements and the overall BM. The identified properties and capabilities are helpful thereby. Furthermore, establishing these capabilities and properties in relation to factors driving BM changes helps developing those flexibility potentials that are required. Overall, this approach supports companies by providing an integrated view on important properties and capabilities that need to be developed to enable BM changes. Moreover, it provides companies the opportunity to identify and prepare for environmental developments early on and thus develop a competitive advantage. 


\section{Implications for research}

Our description of capabilities and properties enabling flexibility in the BM makes a contribution to the literature on BM changes, especially on the capabilities necessary for this purpose. The existing BM literature tends to focus on single capabilities and a detailed description thereof without assigning them to specific BM elements. Our research contributes with new insights by providing an integrated view about capabilities and properties that can be established in single BM elements in order to allow changing more flexible. This should be done by a conscious development of the properties and capabilities described above. However, as important as the flexibility in every single element we see the necessity for enlarging capabilities enabling the overall changeability of the BM. For future research, our results can be improved by identifying additional properties and capabilities in BM elements and the overall BM. This would help to establish a portfolio of suitable capabilities or properties that are helpful to handle changing conditions. Furthermore, we suggest conducting in-depth case studies in particular industries in order to understand industry specific characteristics in terms of factors driving and factors enabling changes in the BM.

\section{CONCLUSION}

The goal of our study was to determine factors that enable a flexible action or reaction according to changing needs. These factors should be identified in single BM elements as well as in the overall BM. Therefore, an exploratory, qualitative study with 20 participating high-technology companies was conducted. It was revealed that flexibility in the BM can be enabled in the form of capabilities or properties developed in both single BM elements and the overall BM in order to act or react to changing needs. Thus, our study provided an integrated view of specific capabilities and properties for changing the BM that was lacking in the previous literature, as presented in the introduction.

The results of this research work need to be viewed in the context of potential limitations. The qualitative research design chosen is, compared to quantitative studies, more of a subjective nature because our research does not rely on rigor calculations. To enhance the quality of our research, we used multiple sources and provided transparency in the research process. In spite of this, the use of multiple sources was limited to interview transcripts as primary data for the elaboration of results. Additional sources, like internal company documents, are only used as secondary data for plausibility checks. The reason for this was the non-availability of documents for most of the companies interviewed; annual reports and information on the number 
of employees, R\&D investments or turnover were also seldom available. Furthermore, the primary data are limited to information from a single interview partner in each company, which bears potentially the risk of a single informant bias. The results are also limited to companies operating in high-technology branches that feature specific characteristics. This reduces the generalizability of results for other industries. Furthermore, we concentrated on business units, divisions or companies in Austria. This is not a major limitation as all companies operate globally. Another limitation is the complexity of the field of study due to multiple interdependences, which raises the difficulty of discussing the topics with the interview partners. Owing to the complexity and diverse understanding of a BM, we had to invest a great deal of effort in analyzing the data and drawing conclusions on the meaning of the BM and on BM changeability. For the emerging literature on business model innovation, these restrictions should be overcome in order to emphasize the strategic importance of consciously rethinking the BM.

\section{References}

Almeida, F., Oliveira, J. \& Cruz, J. (2009). Paths to Innovate Business Models in an Economic Downturn. International Journal of Business and Management, 4(11), 29-37.

Bahrami, H. \& Evans, J. S. (2005). Super-Flexibility for Knowledge Enterprises. Berlin Heidelberg: Springer.

Birks, M. \& Mills, J. (2010). Grounded Theory: A Practical Guide. London: SAGE Publications Ltd.

Bock, A. J., Opsahl, T., George, G. \& Gann, D. M. (2012). The Effects of Culture and Structure on Strategic Flexibility during Business Model Innovation. Journal of Management Studies, 49(2), 279-462.

Bogner, A., Littig, B. \& Menz, W. (2009). Introduction: Expert Interviews - An Introduction to a New Methodological Debate. In A. Bogner, B. Littig \& W. Menz (Eds.), Interviewing Experts (pp. 1-13). London: Palgrave.

Brad, S. (2007). Comprehensive Innovation and its Implications on New HighTech Product Development. Informatica Economică, 42(2), 18-25.

Brehm, C. R. (2003). Organisatorische Flexibilität der Unternehmung: Bausteine eines erfolgreichen Wandels. Wiesbaden: DUV Gabler Edition Wissenschaft.

Capgemini Consulting. (2010). Geschäftsmodell-Innovation: Wer sich nicht neu erfindet, verschwindet. München: Capgemini Consulting.

Charitou, C. D. \& Markides, C. C. (2003). Responses to Disruptive Strategic Innovation. MIT Sloan Management Review, 44(2), 55-63.

Chesbrough, H. (2006). Open Business Models - How to Thrive in the New Innovation Landscape. Boston: Harvard Business School Press.

Chesbrough, H. (2010). Business Model Innovation: Opportunities and Barriers. Long Range Planning, 43(2-3), 354-363. 
Chesbrough, H. W. \& Rosenbloom, R. S. (2002). The role of the business model in capturing value from innovation: evidence from Xerox Corporation's technology spin-off companies. Industrial and Corporate Change, 11(3), 529-555.

De Toni, A. F. \& Tonchia, S. (2005). Definitions and linkages between operational and strategic flexibility. Omega, 33(6), 525-540.

Demil, B. \& Lecocq, X. (2010). Business Model Evolution: In Search of Dynamic Consistency. Long Range Planning, 43(2-3), 227-246.

Deschamps, J.-P. (2005). Different leadership skills for different innovation strategies. Strategy \& Leadership, 33(5), 31-38.

Dottore, A. G. (2009). Business model adaptation as a dynamic capability: a theoretical lens for observing practitioner behaviour. In: BLED 2009 Proceedings. eEnablement: Facilitating an Open, Effective and Representative eSociety (pp. 484-505). Retrieved from http://aisel.aisnet.org/bled2009/11/?utm_source=aisel.aisnet. org\%2Fbled2009\%2F11\&utm_medium=PDF\&utm_campaign= PDFCoverPages

Eisenhardt, K. M. (1989). Building Theories from Case Study Research. The Academy of Management Review, 14(4), 532-550.

EUROSTAT. (2014). Aggregations of manufacturing based on NACE Rev. 2. Retrieved from http://epp.eurostat.ec.europa.eu/cache/ITY_SDDS/Annexes/htec_esms_an3.pdf

Evans, J. S. (1991). Strategic Flexibility for High Technology Manoevres: A Conceptual Framework. Journal of Management Studies, 28(1), 69-89.

Ferguson, S., Siddiqi, A., Lewis, K. \& de Weck, O. L. (2007). Flexible and Reconfigurable Systems: Nomenclature and Review. Paper presented at The ASME 2007 International Design Engineering Technical Conferences \& Computers in Engineering Conference, Las Vegas, Nevada.

Flick, U. (2014). An Introduction to Qualitative Research. London: SAGE Publications Ltd.

Gassmann, O., Frankenberger, K. \& Csik, M. (2014). The Business Model Navigator: 55 Models That Will Revolutionise Your Business. Harlow: Pearson Education Limited.

Gioia, D. A., Corley, K. G. \& Hamilton, A. L. (2012). Seeking Qualitative Rigor in Inductive Research: Notes on the Gioia Methodology. Organizational Research Methods, 00(0), 1-17.

Golden, W. \& Powell, P. (2000). Towards a definition of flexibility: in search of the Holy Grail? Omega, 28(4), 373-384.

Hedman, J. \& Kalling, T. (2003). The business model concept: theoretical underpinnings and empirical illustrations. European Journal of Information Systems, 12(1), 49-59.

Helfat, C. E., Finkelstein, S., Mitchell, W., Peteraf, M. A., Singh, H., Teece, D. J. \& Winter, S. G. (2007). Dynamic Capabilities. Understanding Strategic Change in Organizations. Malden: Blackwell Publishing Ltd. 
KPMG International. (2006). Rethinking the business model. Retrieved from http://us.kpmg.com/microsite/FSLibraryDotCom/docs/Rethinking_the_ business_model.pdf

Krijnen, H. G. (1979). The Flexible Firm. Long Range Planning, 12(2), 63-75.

Magretta, J. (2002). Why Business Models Matter. Harvard Business Review, $80(5), 86-92$.

Mason, K. J. \& Mouzas, S. (2012). Flexible Business Models. European Journal of Marketing, 46(10), 1340-1367.

Massa, L. \& Tucci, C. L. (2013). Business Model Innovation. In: M. Dodgson, D. Gann \& N. Phillips (Eds.), The Oxford Handbook of Innovation Management. New York: Oxford University Press.

Maxwell, J. A. (2005). Qualitative Research Design: An interactive Approach. Thousand Oaks: SAGE Publications, Inc.

Mayring, P. (2010). Qualitative Inhaltsanalyse - Grundlagen und Techniken. Weinheim und Basel: Beltz Verlag.

Mezger, F. (2013, June). Business Model Innovation: Examining the Role of Capabilities and Environmental Contexts. Paper presented at EURAM 2013 Conference, Democratising Management, Galatasaray University, Istanbul, Turkey.

Mitchell, D. W. \& Coles, C. (2003). The ultimate competitive advantage of continuing business model innovation. Journal of Business Strategy, 24(5), 15-21.

Müller, C. (2014). Change of Business Models and the Role of the Business Ecosystem: Creating Flexibility in Business Models by Companies in HighTechnology Industries. Dissertation, Graz University of Technology.

Nair, S., Palacios, M. \& Tafur, J. (2011). Flexibility in airline business models with core competence as an indicator. In: Proceedings of the 15th Air Transport Research Society World Conference, Sydney. Air Transport Research Society. University of British Columbia.

Najmaei, A. (2011). Dynamic Business Model Innovation: An Analytical Archetype. In: International Proceedings of Economics Development and Research: vol 12. (pp. 165-171). Singapure: IACSIT Press.

Osterwalder, A. \& Pigneur, Y. (2010). Business Model Generation: A Handbook for Visionaries, Game Changers, and Challengers. Hoboken: John Wiley \& Sons, Inc.

Palo, T. \& Tähtinen, J. (2011). A network perspective on business models for emerging technology-based services. Journal of Business \& Industrial Marketing, 26(5), 377-388.

Romero, D. \& Molina, A. (2009). Value Co-creation and Co-innovation: Linking Networked Organisations and Customer Communities. In: L. M. Camarinha-Matos, I. Paraskakis \& H. Afsarmanesh (Eds.), Leveraging Knowledge for Innovation in Collaborative Networks, 10th IFIP WG 5.5 Working Conference on Virtual Enterprises, PRO-VE 2009: vol. 307 (pp. 401-412). Berlin Heidelberg: Springer. 
Schneider, S. \& Spieth, P. (2013). Business model innovation: Towards an integrated future research agenda. International Journal of Innovation Management, 17(1), 1-34.

Schuh, G., Friedli, T. \& Kurr, M. A. (2005). Kooperationsmanagement: Systematische Vorbereitung - Gezielter Auf- und Ausbau - Entscheidende Erfolgsfaktoren. Wien, München: Carl Hanser Verlag.

Styles, C. \& Goddard, J. (2004). Spinning the wheel of strategic innovation. Business Strategy Review, 15(2), 63-72.

Teece, D. J. (2007). Explicating Dynamic Capabilities: The Nature and Microfoundations of (Sustainable) Enterprise Performance. Strategic Management Journal, 28(13), 1319-1350.

Teece, D. J., Pisano, G. \& Shuen, A. (1997). Dynamic Capabilities and Strategic Management. Strategic Management Journal, 18(7), 509-533.

The Economist Intelligence Unit. (2005). Business 2010 - Embracing the challenge of change. Retrieved from http://graphics.eiu.com/files/ad_ pdfs/Business\%202010_Global_FINAL.pdf.

Wirtz, B. W. (2011). Business Model Management Design - Instrumente Erfolgsfaktoren von Geschäftsmodellen. Wiesbaden: Gabler Verlag.

Yin, R. K. (2009). Case Study Research: Design and Methods. Thousand Oaks: SAGE Publications.

Zakrzewska-Bielawska, A. (2010). High Technology Company - Concept, Nature, Characteristics. In: N. Mastorakis, V. Mladenov, A. Zaharim \& C. Aida Bulucea (Eds.), Proceedings of the 8th WSEAS International Conference on Management, Marketing and Finance, Recent Advances in Management, Marketing and Finances (pp. 93-98). Penang, Malaysia: WSEAS Press.

Zollenkop, M. (2006). Geschäftsmodellinnovation. Wiesbaden: Deutscher Universitäts-Verlag.

Zott, C. \& Amit, R. (2010). Business Model Design: An Activity System Perspective. Long Range Planning, 43(2-3), 216-226.

Zott, C., Amit, R. \& Massa, L. (2011). The Business Model: Recent Developments and Future Research. Journal of Management, 37(4), 1019-1042.

\section{Abstrakt (in Polish)}

Firmy stojq dziś w obliczu niestabilnych okoliczności, krótkich cyklów życia produktów oraz zmieniajqcych się oczekiwań klientów, w szczególności w obszarze zaawansowanej technologii. W takich warunkach, koncentrowanie się wyłącznie na innowacjach technologicznych i innowacjach produktu nie zapewni uzyskania przewagi konkurencyjnej. Dzisiaj firmy potrzebujq innowacyjnych modeli biznesowych, aby wyróżniać się od swoich konkurentów. Aby skutecznie zmienić modele biznesowe, firmy potrzebujq odpowiednich kompetencji. Tak więc celem tego badania jest określenie, w jaki sposób firmy moga przygotować model/e biznesowy/e by elastycznie reagować na zmiany środowiska, w którym działajq. $Z$ pomocq wybranego projektu badawczo-jakościowego, badamy firm działajqce $w$ branży zaawansowanych technologii. $W$ sumie 20 
firm wzięło udział w naszym badaniu. Wywiady zostały przeprowadzone z prezesami, wiceprezesami, menedżerami produktu lub innymi pracownikami na szczeblu kierowniczym, odpowiedzialnymi za rozwój modelu biznesowego. Badania wykazały, że firmy moga przygotować model biznesowy i jego elementy ex ante (na etapie planowania), rozwijajqc swoje możliwości w celu zwiększenia elastyczności modelu biznesowego. Możliwości te muszq zostać opracowane w odniesieniu do wielu wewnętrznych i zewnętrznych czynników powodujących te zmiany.

Słowa kluczowe: model biznesowy, innowacyjny model biznesu, zdolności do wprowadzania zmian, elastyczność, zaawansowane technologie.

\section{Biographical notes}

Christiana Mueller is a research and teaching assistant at the Institute of General Management and Organization. In her PhD thesis she focused on factors enabling flexibility in business models as well as the importance of the business ecosystem in the changeability of the business model. Furthermore, her research interests include innovation and technology management, strategic management and entrepreneurship.

Stefan Vorbach is a full professor at the Institute of General Management and Organization at Graz University of Technology. His research concentrates on topics including: innovation and technology management, particularly business model innovation, strategic management, entrepreneurship and intrapreneurship. 
